\title{
Online Learning in the Quran Reading Class during Covid-19 Pandemic
}

\author{
M. Wildan Bin H. M. Yahya \\ Universitas Islam Bandung, Indonesia \\ https://orcid.org/0000-0002-7544-1404 \\ Taqia Rahman \\ Universitas Gadjah Mada, Indonesia \\ https://orcid.org/0000-0001-6850-2865
}

\author{
Asep Ahmad Siddiq and Parihat \\ Universitas Islam Bandung, Indonesia \\ https://orcid.org/0000-0003-0617-1305 \\ https://orcid.org/0000-0001-7559-8463
}

\begin{abstract}
The COVID-19 pandemic has forced higher-education institutions to switch to emergency online learning. This situation has also challenged the Muslim communities and institutions across the world to shift to the online mode of teaching Quran and Islamic studies. This research explored undergraduate students' and instructors' perceptions of the emergency online learning of Quran reading in Indonesia. Several aspects were analysed to compare the students' perspective towards face-to-face class versus online learning, including class interaction, learning experience, motivation, satisfaction and comfort level. The study also compared students' Quran reading performance in the online-learning setting with the records from a traditional face-to-face class during the previous year. The survey and performance data were obtained from 923 students. The findings indicated no significant difference in students' performance between Quran reading classes in face-to-face and online classroom settings. Furthermore, although students and instructors felt that some aspects had changed, they generally tended to accept the Quran class in online mode. This is likely because, amidst the pandemic, students and instructors have no other options except to adapt to the rapid change and embrace the transition. Nevertheless, the study indicated signs of fatigue and reduction in the students' acceptance of the Quran online learning over time.
\end{abstract}

Keywords: Quran reading; e-learning; Muslim student; reading skill; Quran recitation 


\section{Introduction}

The spread of the new COVID-19 corona virus has led to serious changes in social interaction and organisation around the world, including the profound interruption of the education sector (Murphy, 2020). As the United Nation's Educational, Scientific, and Cultural Organization (UNESCO) reports, the pandemic has affected the education of more than a billion students in 137 countries worldwide (UNESCO, 2020). The pandemic has resulted in the closure of higher-education institutions and schools all over the world, consistent with government guidelines for implementing social distancing that might help to contain the infection and reduce overall fatalities from the virus (Rashid \& Yadav, 2020). As a result, educators and learners have had to quickly adapt to remote learning online (Carrillo \& Flores, 2020).

This situation also challenged the Muslim communities and institutions across the world to shift to the online mode of teaching Quran and Islamic studies. In many places, such as Africa, Southeast Asia, Malaysia and Pakistan, the Quran learning and reading class traditionally takes place in classes or masjid (mosque) through a face-to-face approach, and assessments use pencil and paper (Raja Yusof et al., 2011).Teaching Quran recitation and its rule (tajweed) is quite different from other subjects; evaluating oral performance is the means of measuring students' skills and learning outcomes (reading, flow, elocution, pronunciation, tempo and segment prolongation).During the session, students typically sit in front of a bench on the floor and the instructor sits at the front of the classroom. The instructor then asks the students to open up the textbook or the Quran and locate a certain page, or surah, to recite together. For practice, the instructor would call on each student individually, listen to his Quran recitation and correct the student's reading with the right pronunciation and tajweed (Noh et al., 2013). No doubt, the face-to-face approach is the best teaching method. However, under the current circumstances, Muslim communities had to shift to the online mode of teaching Quran to reduce face-to-face contact and contain the spread of COVID-19. The rapid, abrupt and forced shift from face-to-face to distance/online learning has introduced not only many questions and constraints on the quality and effectiveness of education, but also opportunities to investigate.

The current study investigated students' performance in Quran-reading skills during emergency online learning in an undergraduate program as a case study in Indonesia. The study also examined students' and instructors' perceptions of the adoption, use and acceptance of Quran online learning during the pandemic. Furthermore, the study explored the key issues of Quran online learning, compared with face-to-face classroom learning. The following sections review the literature addressing the rise of online learning during the COVID-19 pandemic and the resulting learning of Quran reading. The authors then describe the research methods and presents findings and discussion, before drawing conclusions. In particular, this research was performed to: 
1- Measure the performance of students in Quran online learning to examine whether the online learning can potentially substitute the face-to-face learning environment;

2- Investigate the student's level of acceptance of Quran online learning; and

3- Determine the benefit and disadvantages of Quran online learning as compared to face-to-face classroom learning.

The expected result of this study improved understanding regarding the acceptance and effectiveness of online distance learning, especially in a Quranreading class. This research is a valuable contribution to enabling educators and Muslim communities to improve the effectiveness of Quran-reading classes in a situation that forces them to continue learning online.

\section{Literature Review}

\subsection{Growth of Digital Technology for Virtual Learning and Online Education}

The online learning setting for higher-education institutions is an emergency strategy for following the COVID-19 physical-distancing protocol ( $\mathrm{O}^{\prime}$ Brien et al., 2020). A broad variety of terms identifies online learning systems, such as: elearning', remote teaching, distance learning, and emergency education (Murphy, 2020). Online learning delivers educational programmes to students whom distance has isolated from teachers, using the Internet, computer devices, connectivity, and communication technologies. Online learning can be described as educational experiences using various devices (e.g. computers, tablet, smartphones, laptop) with Internet connectivity in synchronous or asynchronous settings (Dhawan, 2020). The organisation of synchronous learning enables students to attend a live class where educators and learners have real-time interactions and direct feedback. However, in asynchronous learning settings, the teaching and learning process does not occur at the same time.

\subsection{Previous Studies on Comparison of Face-to-Face and Online Learning}

Several empirical studies analyse the quality and effectiveness of online learning in comparison to traditional face-to-face learning, from various aspects. Onlinelearning proponents argue that online learning offers several advantages, including eliminating the barrier of distance, as it enables reaching any location that offers a device and Internet access (Ni, 2013); providing learning environments with increased convenience and flexibility (Capra, 2011); offering time cost-effectiveness (Luaran et al., 2014) and enhancing the learning experience with interactive media. However, opponents are aware that online learners might feel isolated and disconnected (McInnerney \& Roberts, 2004) and anxious (Bao, 2020; Sundarasen et al., 2020), thus, possibly reducing students' engagement and participation. Furthermore, for the instructors, preparing and developing content for online learning may be more time-consuming (Capra, 2011) and less comfortable for the instructor (Fein \& Logan, 2003), who may feel a lack of control and the absence of real interaction (Coppola et al., 2001).

Many researchers have performed several studies regarding students' performance in the two different learning modes. For example, Dondorf et al. 
(2016) compared the face-to-face classroom learning setting with an online learning setting in a mathematics course in an undergraduate programme and found that the students in the classroom performed much better than the students in the online learning setting. The result could relate to reduced student motivation in online learning. Patricia (2020), who investigated 270 college students' perception and acceptance of online learning, identified a similar finding in emergency online learning during the pandemic, namely, a reduction in the students' cognitive skills (i.e. knowledge, focus, engagement, involvement and interest). On the contrary, Ni (2013) provided evidence that students' performance in a public administration class, as measured by grades, was independent of the learning mode. Furthermore, Gonzalez (2020) analysed students' performance during the pandemic and concluded that students performed significantly better in the online-learning format, compared to student performance reflected in records of the face-to-face class from the previous year.

\subsection{Quran Recitation Learning}

As of 2015, there were an estimated 1.8 billion Muslims around the world (Pew Research Center, 2019). Approximately $80 \%$ of Muslims are non-Arab, comprising around 1 billion people worldwide today. From the perspective of their religious faith, this large number of people has a common need; they all need to learn the Arabic language to enable them read the Quran. The Muslim views the Quran as Allah's (God's) words, preserved verbatim. Therefore, only Arabic Quran is perceived as the Quran, and Quran in any other language is not considered the Quran but rather the Translated Quran (Abdullah et al., 2016).

All Muslims must use the Arabic Quranic words and verses in their formal prayers (i.e. salat), regardless of whether they are native or non-native Arab speakers (Shihab, 2007). Reading the Quran is one of the strongly recommended practices for Muslims, and it should be performed cautiously so that pronunciation is not mistaken. This mandate has created an unusual social phenomenon, namely, training many non-native Arab Muslims in the complicated phonological rules of the Arabic language, in the context of pronouncing and reciting the Quran correctly (Zarif et al., 2014). The Quran reader must follow a law of pronunciation, intonation, prolongation, stress and stretch, and tempo, to properly perform the recitation, referred to as the tajweed rule (Czerepinski \& Swayd, 2006). For this reason, reading the Quran is one of the challenging tasks for most non-Arab-speaking Muslims, including those in Indonesia.

In many places, instructors of the Quran, often known as Ustaz, have traditionally taught the Quran-reading class in the face-to-face classroom (Raja Yusof et al., 2011). However, in the last 10 years, several countries have developed the Quran online class for Muslims who may not have convenient access to a masjid (mosque) or madrasah (Islamic school). The Quran online class mostly takes place in the synchronous learning environment, where the students attend live lectures or online private classes using video conferencing software and a program that displays pages of the Quran. The student reads the verse and the tutor corrects him if he makes a mistake. Occasionally, the class also 
takes place in asynchronous learning environments, where the student learns individually from speech-recognition software for the Quran, capable of automatically checking the tajweed and identifying errors in Quran recitation. Despite this increasing trend, Quran online learning has not been massively adopted by many Muslims around the world, and to date, literature regarding the students' acceptance and its effect on Quran-reading performance has been limited.

\section{Methodology}

\subsection{Research Site, Participant and Research Design}

This study aims to investigate students' performance in an online Quran class and their acceptance during the COVID-19 pandemic of the emergency online learning in undergraduate programs at the Universitas Islam Bandung (UNISBA), Bandung, Indonesia. The students' performance (grades) in six online remote classes held between May 20 and August 21, 2020 (second semester of the 2019/2020 academic year) were compared to students' performance records from eight face-to-face classes run in 2019.The teaching process during online class, including number of course meeting, course content and tools, and assessment indicators, was designed as closely as possible to faceto-face Quran class performed in previous years to provide comparable conditions. The assessment indicators to gauge the students' performance are later discussed in the next section. All procedures were granted the university's ethical-practice approval. The Quran reading class is one of the required courses at the university, designed for all students in any undergraduate study programme and offered to the students three times every semester. Students who earn a minimum grade of 60 points get a certificate, required for graduation. Otherwise, a remedial class is offered to the student who does not meet the course criteria. The course has been implemented for more than 30 years, regularly conducted in classes through a face-to-face approach and assessed through class-interaction. However, following the rise of COVID-19 cases and starting on March 14, 2020, the university shifted to emergency remote education using online settings.

Besides the student performance records, this study also used student survey responses from six Quran online classes to assess the students' perception of the online learning system. Online questionnaires were distributed to the students prior to the course and at the end of the lecture series. Students' participation was anonymous and voluntary, and those who agreed were required to complete the consent form before filling out the questionnaires. A total of 937 students were asked, but only 923 students (557 female and 366 male) completed the form. In the pre-course questionnaires, students were required to provide their gender, year of study, age, study program, experiences in reading Quran, and duration of study they expected to enable them to read Quran fluently. In the post-course questionnaires, students were asked about their perception of Quran online learning. The questionnaire for students included demographic items, questions to assess students' attitude towards face-to-face Quran class versus Quran online learning, learning experience, learning comfort, motivation to participate in the class, cognitive engagement, and class interaction. The 
questionnaire was adopted from the work by Ni (2013), (Dondorf et al., 2016) and (Luaran et al., 2014) about the issues related to students during online education. The questions are presented later in Figure 2 and Figure 3 in results and discussions section. The respondents' average age was $19.9(\mathrm{SD}=1.84)$ and the reported course disciplines were: $26.82 \%$ Economics and Business, $17.7 \%$ Religion and Education, 12.9\% Engineering, 14.4\% Basic Science, 8.2\% Law and $4.4 \%$ other. Furthermore, to investigate the instructors' perceptions, they also received the questionnaire. The questionnaire for instructors included demographic items, questions to assess instructors' attitude towards the changing role during online learning, instructor preparation program (demand on their time), and interaction barriers. The questionnaire was adopted from the paper presented by Kebritchi et al. (2017) concerning the issues related to instructors during online education. The questions are presented later in Figure 5 in results and discussions section. Instructors who agreed to participate each received an online questionnaire package to complete and return to the researchers. A total of 11 instructors responded.

\subsection{Tools and Mode of Teaching}

The Bilhikmah Quranic approach that the author developed in the early 1990s was used as the learning approach to Quran reading. It is a phonetic method consisting of four books, starting with training in single Arabic letters with all vowel symbols (harakaat) in Book 1 and the introduction of the connected form of the Arabic letters in Book 2. Further, in Book 3, the symbols and letters are combined with the progressive improvement of tajweed rule. In addition, Book 4 provides comprehensive rules of tajweed for advanced students/users. For each book, the instructor of Bilhikmah begins with the overview of the basic rules and how to speak the written word or letter, then asks the students to read individually one set of phrases or more. The set of phrases that are presented in Bilhikmah books are all derived from the Quran. The students must be competent in each lesson before progressing to the next book. UNISBA has used the Bilhikmah approach continuously to teach undergraduate students to read the Quran.

In order to create equivalent learning experiences between the two teaching modes (face-to-face and online), the material content and the arrangement were structured to be as similar as possible. Table 1 displays the comparison of the content delivery across the two teaching modes. The online teaching session included 14 teaching meetings, each lasting 60 minutes, precisely the same duration as the pre-lockdown face-to-face classroom meeting. Furthermore, all course materials were delivered using Zoom teleconference software. The students received physical and digital versions of the textbook and could choose and use the version they found more convenient. During the learning process, PowerPoint presentations replaced the blackboard. The instructor would display the Arabic alphabet or Quran verses (depending on the class) to recite together. The instructor would initially demonstrate the correct pronunciation of the Arabic letters or the Quran verses, and the students would subsequently repeat and replicate the recitation. During practice, the individual student would have a private lesson with the instructor for about five-to-ten minutes. Like the face- 
to-face classroom, the instructor would call the students one-by-one to evaluate their recitation. The remaining students were asked to mute their microphones and practice on their own while awaiting their turn. Students with questions or comments could type the question in the comments box or speak directly by turning on their microphones.

Table 1. Comparison of Content Delivery

\begin{tabular}{lll}
\hline Mode of Teaching & $\begin{array}{l}\text { Classroom } \\
\text { (control group) }\end{array}$ & Online-learning \\
\hline Textbook and readings for tajweed theory & Bilhikmah & Bilhikmah digital \\
Discussions & Classroom interactive & Video conference \\
Lectures & Instructor and board & PowerPoint \\
Reading Assessment & Classroom interactive & Video conference \\
\hline
\end{tabular}

\subsection{Students' Performance Assessment Indicators}

To assess the students' performance during Quran online learning, similar to face-to-face classroom learning, students were divided into different subclasses based on their pre-course placement-test result. The placement addressed the wide range of students' skills in reading the Quran. Table 2 shows the indicators and performance grades, according to the number of students who were placed in seven different sub-classes based on their Quran reading skill. A similar Quran reading-skills indicator system also appeared in a study by Supriyadi and Julia (2019). The placement test was administered before the course started. The students were individually asked to read the random verse in the Qur'an and the instructor assessed the reading. In addition, the same tests were performed again at the end of the course to evaluate the students' improvement in reading the Quran.

Table 2. Quran Reading Skills Indicators

\begin{tabular}{llll}
\hline No. & Sub-class & Key Features & $\begin{array}{l}\text { Performance } \\
\text { grade }\end{array}$ \\
\hline 1 & Very & Fdvanced & $\begin{array}{l}\text { Fluently and correctly reading cursive letters } \\
\text { Correctly applying and comprehending the tajweed rule } \\
\text { Reciting the Quran with correct tempo and rhythm }\end{array}$ \\
\hline 2 & Advanced & $\begin{array}{l}\text { Fluently and correctly reading cursive letters } \\
\text { Fluently reciting the makhraj } \\
\text { Somewhat correctly applying the tajweed rule in } \\
\text { reading }\end{array}$ & $70-79$ \\
\hline 3 & Pre-advanced & $\begin{array}{l}\text { Fluently and correctly reading cursive letters } \\
\text { Reciting the Quran with a slow tempo but not halting } \\
\text { Still incorrectly applying the tajweed rule in reading }\end{array}$ & \\
\hline 4 & Intermediate & $\begin{array}{l}\text { Be able to read the cursive letters but only 3 to 4 letters } \\
\text { Be able to read the makhraj is still incorrect or swapped }\end{array}$ & $50-59$ \\
\hline 5 & Pre- & $\begin{array}{l}\text { Be able to acknowledge single Arabic letters but some } \\
\text { letters are still frequently swapped } \\
\text { Slowly or haltingly reading the cursive letters }\end{array}$ & $40-49$ \\
\hline 6 & Elementary & $\begin{array}{l}\text { Be able to read the single Arabic letters but not the } \\
\text { cursive letters }\end{array}$ & $30-39$ \\
\hline 7 & Beginner & $\begin{array}{l}\text { Not be able to or barely acknowledge single Arabic } \\
\text { letters with the vowel }\end{array}$ & $<29$ \\
\hline
\end{tabular}




\section{Result and Discussion}

\subsection{Students' Performance}

The researchers obtained a total of 923 students' performance data (grade)in the Quran reading class in the online-learning mode, then compared them with the control-sample data of 1,239 students in the Quran reading class conducted in face-to-face learning mode in 2019 (before the pandemic). Table 3 shows the comparison results.

Table 3. Performance of Students in Online vs. Classroom Learning

\begin{tabular}{ccccc}
\hline \multirow{2}{*}{ Mode of learning } & \multirow{2}{*}{$\begin{array}{c}\text { Number of } \\
\text { students }\end{array}$} & \multicolumn{3}{c}{ Average Performances } \\
\cline { 3 - 5 } & 1,239 & $\begin{array}{c}\text { Pre-course } \\
\text { test }\end{array}$ & Post-test & Differences \\
\hline Classroom learning & 923 & 66.15 & 70.95 & +4.80 \\
Online learning & 65.32 & 70.31 & +4.99 \\
\hline
\end{tabular}

On average, the students in the face-to-face classroom improved their performance from 66.15 on the placement test to 70.95 on the post-course test. Comparatively, in the online-learning students achieved, on average, 65.32 on the pre-course test and 70.31 on the post-course test. Thus, the face-to-face classroom students increased their performance by $4.80 \%$, whereas the students in the online setting improved their performance by $4.99 \%$.In comparison, Figure 1 displays the results for each individual student. The students' grades on the pre-course test appear on the $\mathrm{x}$-axis, while the results of the post-course test appear on the y ordinate. The blue dotted line displays the trend line for the students' performance in face-to-face learning mode whereas the orange dashed line represents the trend line for online-learning students.

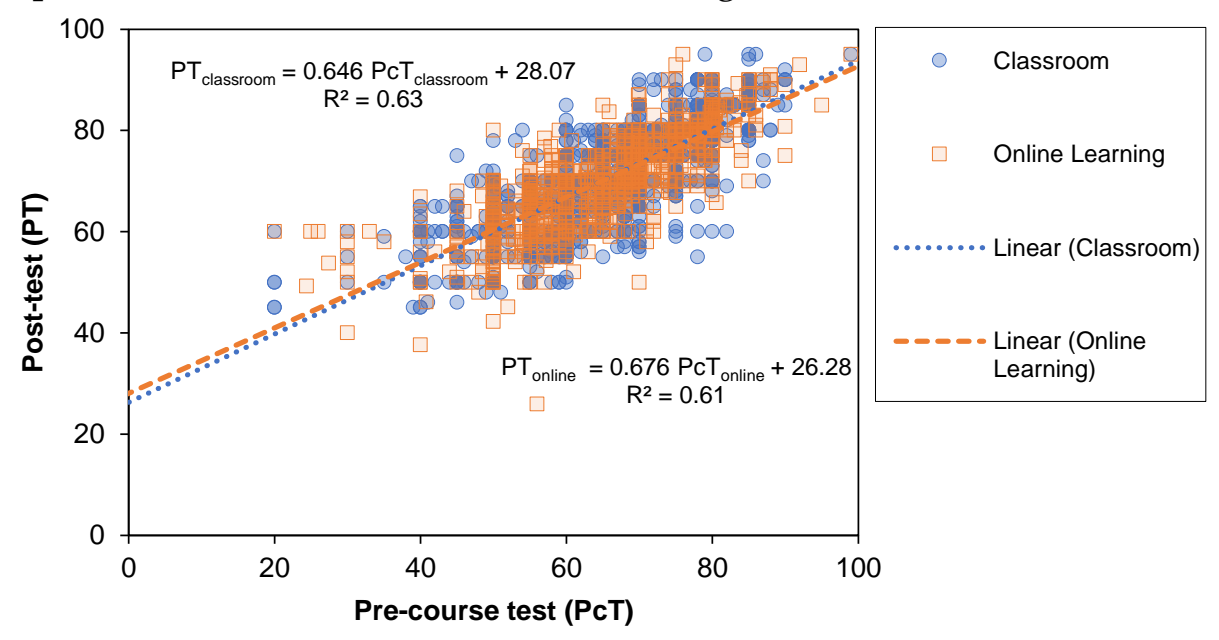

Figure 1. Performance of Students in Online vs. Classroom Learning - Individual Results

The graph illustrates both trend lines showing a steady increase, indicating that students who performed well on the pre-course test were more likely to score better on the post-test, and vice versa. The correlation coefficient of the classroom trend line is 0.63 , while the coefficient for the online-learning trend line is 0.61 . Several outliers were found for both learning modes. In general, the result in the figure shows that students performed similarly in the face-to-face classroom and online-learning mode. Moreover, the trend line of the online-class 
students was slightly higher than that of the face-to-face students. This is likely due to the lack of students' performance data at a grade below 40 , the limitation of this study.

Furthermore, Welch's t-test, which Ruxton (2006) recommends for samples with unequal variances and sample sizes, was performed to assess the statistical significance. The results indicated no statistical significance between the online and classroom learning in this research $(\mathrm{p}=0.1203)$, indicating that student performance in Quran reading, as measured by grade (on a scale of 0-100), is independent of the learning mode. The result is similar to findings in previous literature (Gonzalez, 2020; McLaren, 2004; Ni, 2013), suggesting that students performed comparably in both face-to-face and online-learning modes.

\subsection{Students' Perceptions}

In addition to the performance assessment, the survey was also administered after the course to assess the students' perception of and satisfaction with the online course, compared to traditional classroom learning. Several factors were analysed, including class interaction, learning experience, motivation, satisfaction and comfort level, and Figure 2 presents the results. In terms of learning comfort, the majority of the students reported a 'medium' feeling about the comfort level of participating in the online format. Surprisingly, 25\% and 3\% of students perceived a moderate and a significant increase, respectively, in comfort level during the online class. Previous research supports the finding (Hanafi et al., 2019), stating that Quran lessons in online format can enhance students' comfort because the environment is less intimidating than the traditional classroom, for students who are reserved and afraid of direct and open feedback from either the instructor or their classmates. When asked about the quality of their learning experience, more students perceived that the experience improved when the class performed in the online setting, compared to the traditional classroom learning. However, despite the positive opinions about online learning, the majority of the students felt that the quality of interaction with other students and the instructor decreased, along with a slightly reduced motivation level. Motivation is one of the important keys affecting students' behavioural intention to achieve a goal during the learning process. Highly motivated students are likely to participate in self-monitoring activities that support them in achieving their goals (Kemp et al., 2019). Thus, the reduction in motivation is an essential challenge during the shift to an online-learning setting.

The surveys also asked the students about their perception of the online learning setting, on a scale of 2 (strongly agree) 1 (agree), 0 (neutral), -1 (disagree) and -2 (strongly disagree). The results, the distributions and the average score of the students' perceptions appear in Figure 3. Students tended to feel that online learning is useful during studies but is more time-consuming than face-to-face learning, although most of them perceived the statement neutrally. The majority of the students tended to disagree that online learning can provide more benefits than drawbacks. Moreover, most students claimed that they have learned more effectively in the face-to-face learning setting. 
Although students felt that some aspects had slightly changed when they moved to online learning, they generally tended to accept online learning. This could be because the pandemic has likely made the students initially hesitant to change more accepting of the emergency online-learning mode. After all, they had no other options than adjusting to this new situation. These results also accorded with the research by Ayebi-Arthur (2017), a case study of college students in New Zealand, severely affected by earthquake activity. The author observed that the college students were more open to emergency online learning after the catastrophic incident.

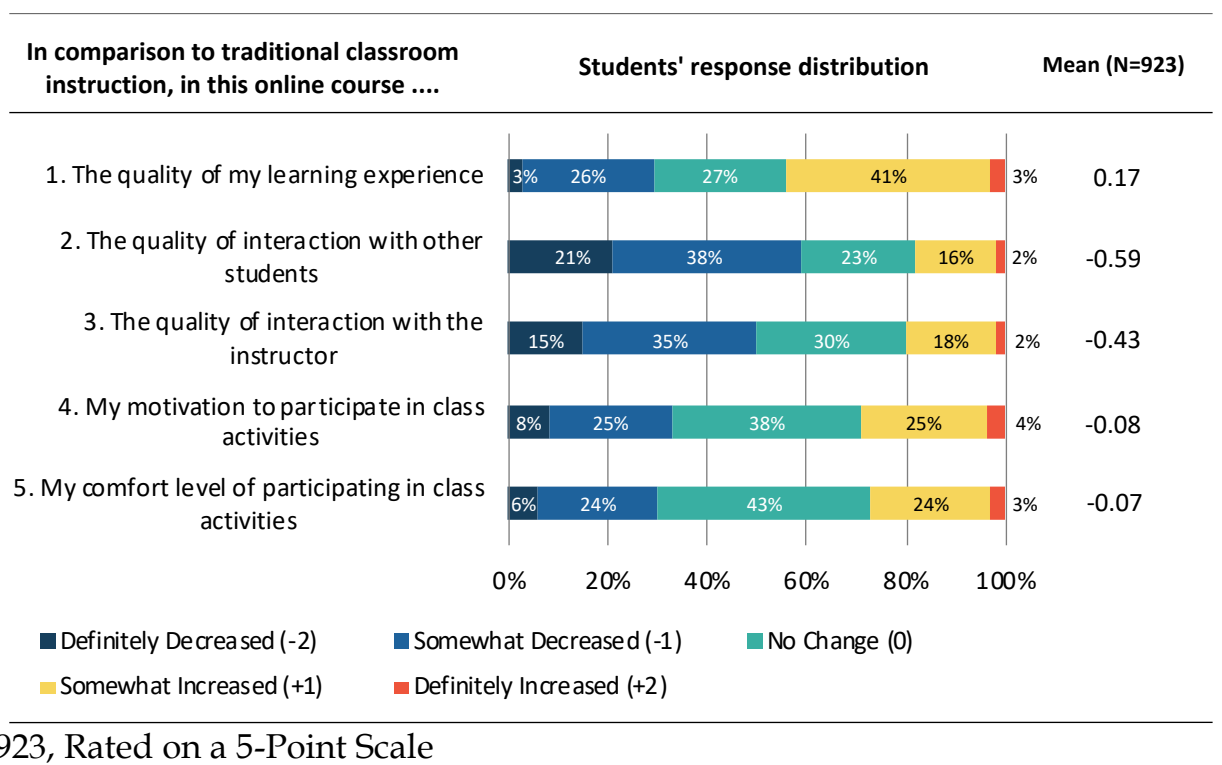

$\mathrm{N}=923$, Rated on a 5-Point Scale

Figure 2. Post-Course Questionnaire about Online Learning Interaction

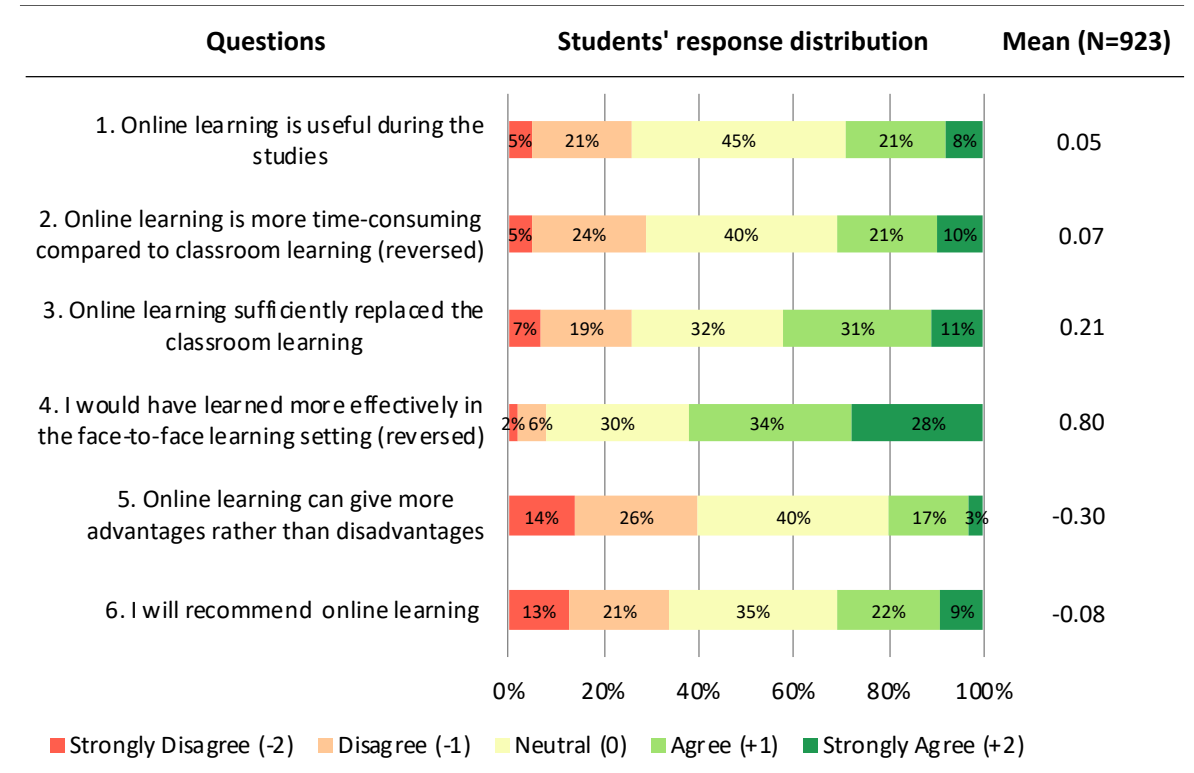

$\mathrm{N}=923$, Rated on a 5-point scale (red = strongly disagree $(-2)$, yellow $=$ neutral $(0)$, green $=$ strongly agree $(+2))$

Figure 3. Post-Course Surveys about the Students' Perception of the Online Learning 
Furthermore, students are susceptible to 'online learning fatigue', the sense of boredom and exhaustion that students feel from attending many live lectures multiple times (Wiederhold, 2020). On a variety of occasions, the continuous use of technology may cause fatigue. Sitting for a prolonged amount of time in the same setting will induce both emotional and physical drains. In this study, to investigate the students' perception of online learning repeatedly over time, the responses were analysed for two different periods; May to June $2020(N=228)$, the early stage of online learning, and July to August $(N=694)$, the stage when online learning had been fully implemented. For each period, the students were asked whether they recommend the Quran recitation class in online learning mode. The results appear in Figure 4.

The findings showed that students' acceptance of the online mode in the learning period of July to August (-0.53) was significantly lower than the early period of the online-learning shift $(0.21)$. The t-test result showed the statistically significant difference between the students' acceptance during the early period and several months later $(p=0.000)$. Students likely were still excited the first time they switched to emergency online learning and gradually became exhausted after several months with countless online classes. Previous studies supported such results (Bao, 2020; Lee, 2020; Sundarasen et al., 2020; Wang \& Zhao, 2020), suggesting that online learning can be one main cause of student stress and anxiety.

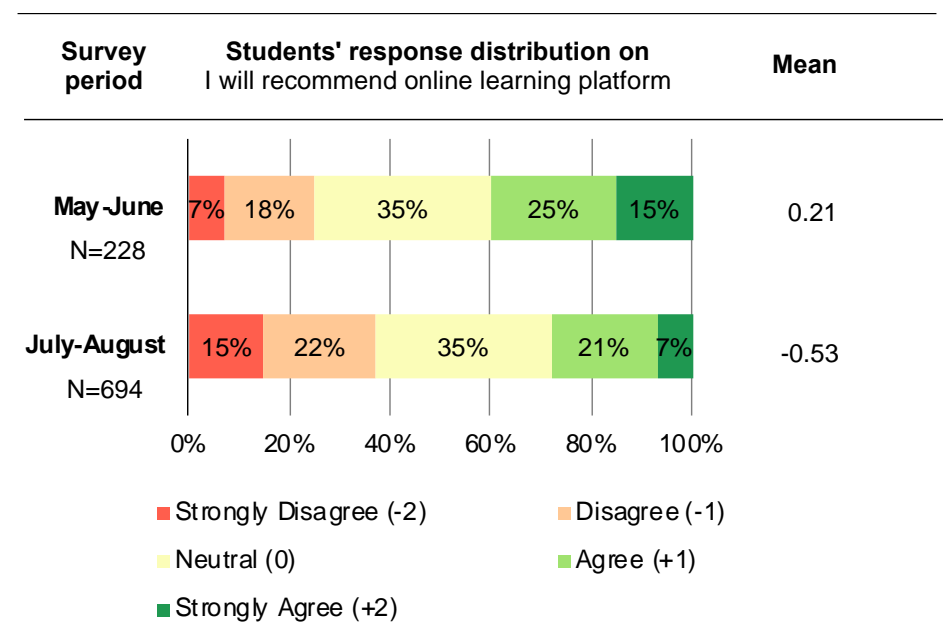

Different Periods

$\mathrm{N}=923$, Rated on a 5-point scale

Figure 4. Students' Acceptance of Quran Recitation Class in Online Mode over Two

\subsection{Instructors' Perceptions}

The instructors were also asked to fill out a questionnaire after the course, about their perceptions of the online-learning mode. The questionnaire package contained questions from previous research, on several issues and challenges related to instructors, including time management, transitioning from face-toface to online, instructors' lack of interest in online courses and communication barriers(Anderson et al., 2011; Crawley et al., 2009; Kebritchi et al., 2017). The results appear in Figure 5. 


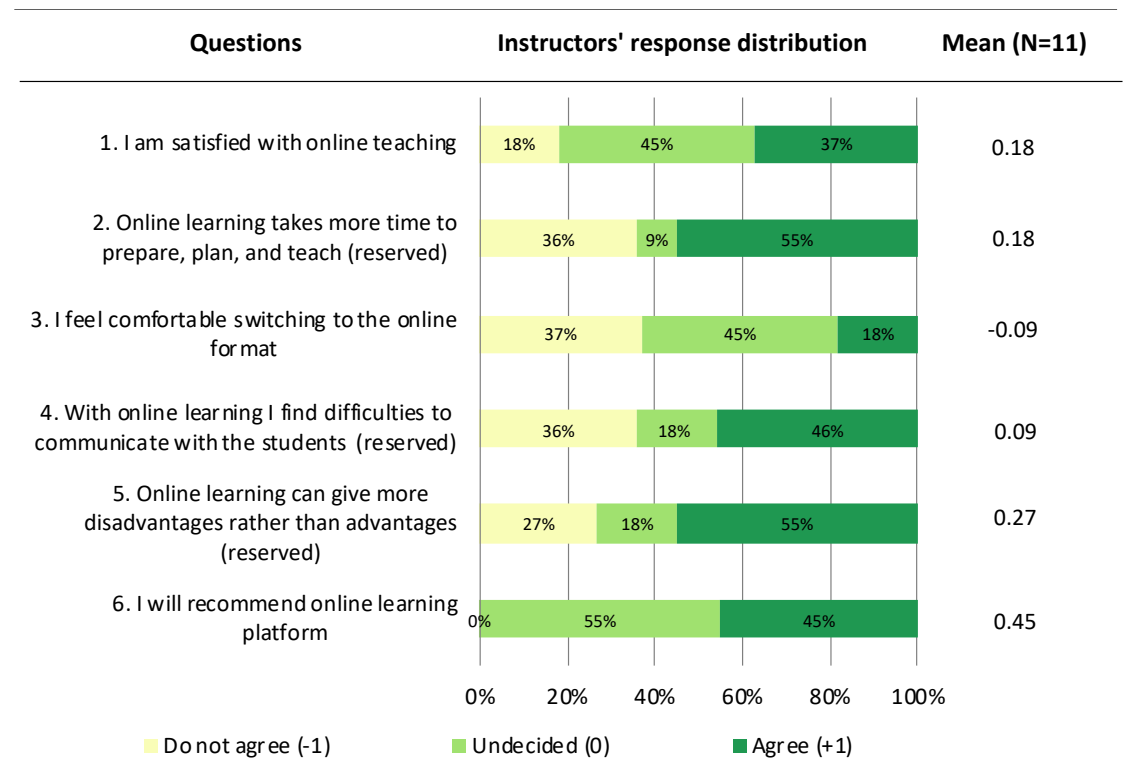

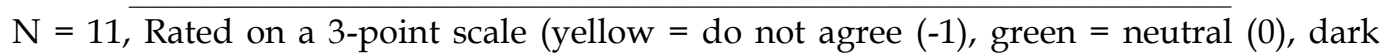
green agree $(+1))$.

Figure 5. Post-Course Questionnaire about the Online-Learning Platform from Instructor's Perspective

Feedback responses were obtained from 11 instructors. Although the majority tended to feel satisfied with the online-learning format, they also felt that it takes quite a bit more time than face-to-face learning to design, prepare and teach the online class $n=6(55 \%)$. The result agreed with previous studies (Capra, 2011; Cavanaugh, 2005; Humphries, 2010), which show that online learning could demand more instructor time. During the pandemic, the instructors had to redesign and re-plan the curriculum, develop the content delivery and create the new assessment method. This new activity resulted in overwork, anxiety and stress among instructors and academic staff (Rashid \& Yadav, 2020). Moreover, in this study, the instructors did not feel comfortable switching to the online setting $n=4(36 \%)$ and had difficulties interacting with the students $n=5(45 \%)$. The discomfort may have been associated with their concerns about interacting and communicating with the students; the surveys showed that the instructors felt the reduced interaction with the students. Although in online learning, the instructor is still able to communicate with students visually and audibly, it may be the lack of the personal touch that reduces the effectiveness of the communication. In the online-learning format, the instructors have difficulty taking cues from students' verbal and nonverbal interaction that they usually had in the face-to-face classroom (Crawley et al., 2009). Instructors' comfort level with technology and online education is important, because it affects instructors' desire to teach in an online setting (Fein \& Logan, 2003; Osika et al., 2009). Making sure that the instructors are comfortable with new technology and how to utilize it is important for its effectiveness.

However, despite the issues arising during the online study, the majority of instructors were satisfied with the online class and tended to recommend the Quran class performed in the online-learning setting. Although most of them 
perceived it neutrally, surprisingly, no instructor rejected the online-learning format. Similar to the student observation, it seems that amidst the pandemic, instructors have no other choice but to adjust to the dynamic situation and embrace the transition.

Overall, students and instructors tend to accept the Quran class in online mode. The study indicated that altering the Quran reading class to an online setting can be quite simple. Commonly used video-conferencing software can accommodate the main features of learning Quran reading, namely, the real-time audio, visual and text. Also, students are now regularly taught in online-learning formats during the pandemic, and they seem to have adapted to the change. Despite all these promising adjustments, several issues relating to online students and instructors were identified. Issues relating to students covered their readiness, reduced motivation, difficulties in classroom communication, potential fatigue and rising anxiety. Issues related to instructors included reduced comfort level, difficulties in classroom interaction and time-management concerns. Highereducation institutions play a critical role in improving the standard of online education by helping students, instructors and the development of the learning content (Kebritchi et al., 2017). The potential fatigue and anxiety that the student feels during online learning must be relieved in many ways, to make sure that students can successfully and effectively participate in online learning (Bao, 2020). Proactive initiatives to support the well-being of students and academic staff are now required during the pandemic (Flores, 2020). Regarding issues related to instructors, the higher-education institution must provide sufficient training and professional development for the instructor on how to use the current technology, as well as how to engage in online classes. During the pandemic, the instructors are teaching in the context of emergency online learning, but not necessarily properly designed learning (Murphy, 2020). Thus, training is expected to help solve these issues in the future.

In addition, higher-education institutions can continuously assess-through polls, evaluations, surveys, interviews and analysis of course design - what contributes to better and more effective online learning during this pandemic. As the assessment continues and the effectiveness of teaching and learning in the online setting improves, we hope that students, too, can adapt to and benefit from this new emergency online learning more effectively. Furthermore, to improve the students' learning experience during the emergency online learning in the Quran reading class, instructors can develop such strategies as incorporating multimedia to enhance the teaching content delivery. The rise of the adoption of speech processing and recognition software for the Arabic language (Noor Jamaliah et al., 2015) could benefit developing and incorporating Quranic-verse-recitation recognition software into the design of Quran online courses. The software can automatically check the tajweed, identify errors in Quran recitation and show exactly where errors have occurred (Mohammed et al., 2015). This option provides students with the chance to make numerous attempts to master the Quran reading, without the need for instructor supervision. 


\section{Conclusion}

This research explored undergraduate students' and instructors' perceptions and acceptance of the emergency Quran online learning in Indonesia. Several aspects were analysed, including class interaction, learning experience, motivation, satisfaction and comfort level. The study also compared students' Quran-reading performance on an online learning platform with the records from a traditional face-to-face class from the previous year. The survey and performance data were obtained from 923 students of the Universitas Islam Bandung (Indonesia), between May and August 2020, when all universities had to shift to distance learning because of the corona virus outbreak. The findings indicated no significant difference in student performance between the online mode and the face-to-face classroom setting. Furthermore, although students and instructors felt that some aspects had changed, they generally tended to accept the Quran class in online mode. This is likely because, amidst the pandemic, students and instructors have no other options except to adapt to the rapid change and embrace the transition.

While the online class provides a comparably effective learning alternative, we should realise that online learning has its benefits and drawbacks. It is reasonable that students feel fatigue or less motivated toward online learning. The study indicated the reduction over time in the students' acceptance of the Quran online learning. It is likely that students were still excited when they first switched to learning new technology and gradually became exhausted after several months with countless online classes. Providing students with a support plan, including phone numbers, email or online messaging where students can contact staff, is important. In addition, it is necessary to provide proactive initiatives to support the well-being of the students, instructors and academic staff during the pandemic. We conclude that the online-learning setting is practical, affordable and adaptable for use with Quran recitation classes in Indonesia, beyond the prevailing pandemic, as students and instructors seem to have become more open to the online learning setting.

\section{Limitations}

There are some limitations to this study. The initial student performance (grade) in the face-to-face class and the online class were not at the same level and could cause bias in the results (Hanafi et al., 2019). The research also had insufficient data for students with an initial performance at a grade below 40; thus, the performance of students with very limited Quran-reading skills was not known. Another limitation of this research is that during the study, students were asked about their perception of Quran online learning as compared to traditional faceto-face learning. However, some students had not previously enrolled in the traditional face-to-face Quran class in the university, and thus, they had no comprehensive picture of the differences between the Quran class face-to-face and in an online setting. Nevertheless, the pre-course survey result reveals that the majority of the students had learned the Quran for years; hence, it is expected that this would provide them with the clue of the typical traditional Quran learning. 


\section{References}

Abdullah, M. S., Rahman, M. M. H., Pathan, A. K., \& Shaikhli, I. F. A. (2016). A practical and interactive web-based software for online Qur'Anic Arabic learning. Paper presented at the 6th International Conference on Information and Communication Technology for The Muslim World (ICT4M).

Anderson, D., Sandra, I., \& Standerford, N. (2011). Feedback please: Studying self in the online classroom. International Journal of Instruction, 4.

Ayebi-Arthur, K. (2017). E-learning, resilience and change in higher education: Helping a university cope after a natural disaster. E-Learning and Digital Media, 14(5), 259274. https://doi.org/10.1177/2042753017751712

Bao, W. (2020). COVID-19 and online teaching in higher education: A case study of Peking University. Human Behavior and Emerging Technologies, 2(2), 113-115. https://doi.org/10.1002/hbe2.191

Capra, T. (2011). Online education: Promise and problems. MERLOT Journal of Online Learning and Teaching, 7(2), 288-293.

Carrillo, C., \& Flores, M. A. (2020). COVID-19 and teacher education: A literature review of online teaching and learning practices. European Journal of Teacher Education, 122. https://doi.org/10.1080/02619768.2020.1821184

Cavanaugh, J. (2005). Teaching online-A time comparison. Online Journal of Distance Learning Administration, 8(1), 1-9.

Coppola, N. W., Hiltz, S. R., \& Rotter, N. (2001). Becoming a virtual professor: Pedagogical roles and ALN. Proceedings of the 34th Annual Hawaii International Conference on System Sciences.

Crawley, F. E., Fewell, M. D., \& Sugar, W. A. (2009). Researcher and researched: The phenomenology of change from face-to-face to online instruction. Quarterly Review of Distance Education, 10(2), 165-176.

Czerepinski, K. C., \& Swayd, A.-s. D. A. R. (2006). Tajweed rules of the Qur'an. Dar AlKhair Islamic Books Publisher Jeddah.

Dhawan, S. (2020). Online learning: A panacea in the time of COVID-19 crisis. Journal of Educational Technology Systems, 49(1), 5-22. https://doi.org/10.1177/0047239520934018

Dondorf, T., Breuer, R., \& Nacken, H. (2016). Classroom vs. e-learning: A case study on the performance of students in different learning scenarios. Paper presented at 8 th International Conference on Education and New Learning Technologies, Barcelona, Spain.

Fein, A. D., \& Logan, M. C. (2003). Preparing instructors for online instruction. New Directions for Adult and Continuing Education, 2003(100), 45-55. https://doi.org/10.1002/ace.118

Flores, M. A. (2020). Preparing teachers to teach in complex settings: Opportunities for professional learning and development. European Journal of Teacher Education, 43(3), 297-300. https://doi.org/10.1080/02619768.2020.1771895

Gonzalez, T., de la Rubia, M., Hincz, K., Lopez, M. C., Subirats, L., Fort, S., \& Sacha, G. M. (2020). Influence of COVID-19 confinement in students' performance in higher education. https://doi.org/https://doi.org/10.35542/osf.io/9zuac

Hanafi, Y., Murtadho, N., Ikhsan, M. A., Diyana, T., \& Sultoni, A. (2019). Student's and instructor's perception toward the effectiveness of E-BBQ enhances Al-Qur'an reading ability. International Journal of Instruction, 12, 51-68. https://doi.org/10.29333/iji.2019.1234a

Humphries, S. (2010). Five challenges for new online teachers. Journal of Technology Integration, 2(1), 15-24. 
Kebritchi, M., Lipschuetz, A., \& Santiague, L. (2017). Issues and challenges for teaching successful online courses in higher education: A literature review. Journal of $\begin{array}{llll}\text { Educational Technology } & \text { Systems, } & \text { 46(1), }\end{array}$ https://doi.org/10.1177/0047239516661713

Kemp, A., Palmer, E., \& Strelan, P. (2019). A taxonomy of factors affecting attitudes towards educational technologies for use with technology acceptance models. British Journal of Educational Technology, 50(5), 2394-2413. https://doi.org/10.1111/bjet.12833

Lee, J. (2020). Mental health effects of school closures during COVID-19. The Lancet Child \& Adolescent Health, 4(6), 421. https:/ / doi.org/10.1016/S2352-4642(20)30109-7

Luaran, J. E., Samsuri, N. N., Nadzri, F. A., \& Rom, K. B. M. (2014). A Study on the student's perspective on the effectiveness of using e-learning. Procedia - Social and Behavioral Sciences, 123, 139-144. https://doi.org/https://doi.org/10.1016/j.sbspro.2014.01.1407

McInnerney, J. M., \& Roberts, T. S. (2004). Online learning: Social interaction and the creation of a sense of community. Journal of Educational Technology \& Society, 7(3), 73-81. http://www.jstor.org/stable/jeductechsoci.7.3.73

McLaren, C. H. (2004). A comparison of student persistence and performance in online and classroom business statistics experiences. Decision Sciences Journal of Innovative Education, 2(1), 1-10. https://doi.org/10.1111/j.0011-7315.2004.00015.x

Mohammed, A., Sunar, M. S., \& Salam, M. S. (2015). Quranic verses verification using speech recognition techniques. Jurnal Teknologi, 73. https://doi.org/10.11113/jt.v73.4200

Murphy, M. P. A. (2020). COVID-19 and emergency e-learning: Consequences of the securitization of higher education for post-pandemic pedagogy. Contemporary Security Policy, 41(3), 492-505. https:// doi.org/10.1080/13523260.2020.1761749

$\mathrm{Ni}, \mathrm{A}$. Y. (2013). Comparing the effectiveness of classroom and online learning: Teaching research methods. Journal of Public Affairs Education, 19(2), 199-215. https://doi.org/10.1080/15236803.2013.12001730

Noh, M. A. C., Hussien, A., Ghani, O., \& Suhid, A. (2013). The study of Quranic teaching and learning: A review in Malaysia and United Kingdom. Middle-East Journal of Scientific Research, 15(10), 1338-1344.

Noor Jamaliah, I., Mohd Yamani Idna, I., Yusoff, M. Y. Z. M., \& Asma, A. (2015). The problems, issues and future challenges of automatic speech recognition for Quranic verse recitation: A review. Al-Bayan: Journal of Qur'an and Hadith Studies, 13(2), 168-196. https://doi.org/https://doi.org/10.1163/22321969-12340024

O’Brien, W., Adamakis, M., O' Brien, N., Onofre, M., Martins, J., Dania, A., Makopoulou, K., Herold, F., Ng, K., \& Costa, J. (2020). Implications for European physical education teacher education during the COVID-19 pandemic: A crossinstitutional SWOT analysis. European Journal of Teacher Education, 1-20. https:// doi.org/10.1080/02619768.2020.1823963

Osika, E., Johnson, R., \& Butea, R. (2009). Factors influencing faculty use of technology in online instruction: A case study. Online Journal of Distance Learning Administration, 12(1). https://www.westga.edu/ distance/ojdla/spring121/osika121.html

Patricia, A. (2020). College students' use and acceptance of emergency online learning due to COVID-19. International Journal of Educational Research Open, 100011. https://doi.org/https://doi.org/10.1016/j.ijedro.2020.100011

Pew Research Center. (2019). 10 countries with the largest Muslim populations, 2015 and 2060. https://www.pewresearch.org/fact-tank/2019/04/01/the-countries- 
with-the-10-largest-christian-populations-and-the-10-largest-muslimpopulations/ft_19-03-29_muslimchristianpopulations_muslim/

Raja Yusof, R. J., Zainuddin, R., \& Mohd Yusoff, Z. (2011). Learning methods and problems of Qur'an reciters (Malays and Africans). QURANICA - International Journal of Quranic Research(1), 17-38.

Rashid, S., \& Yadav, S. S. (2020). Impact of Covid-19 pandemic on higher education and research. Indian Journal of Human Development, 14(2), 340-343. https://doi.org/10.1177/0973703020946700

Ruxton, G. D. (2006). The unequal variance t-test is an underused alternative to Student's t-test and the Mann-Whitney $U$ test. Behavioral Ecology, 17(4), 688-690. https://doi.org/10.1093/beheco/ark016

Shihab, M. Q. (2007). Membumikan Al-Quran: Fungsi dan peran wahyu dalam kehidupan masyarakat. Mizan Pustaka.

Sundarasen, S., Chinna, K., Kamaludin, K., Nurunnabi, M., Baloch, G. M., Khoshaim, H. B., Hossain, S. F. A., \& Sukayt, A. (2020). Psychological impact of COVID-19 and lockdown among university students in Malaysia: Implications and policy recommendations. International Journal of Environmental Research and Public Health, 17(17), 1-13. https:// doi.org/10.3390/ijerph17176206

Supriyadi, T., \& Julia, J. (2019). The problem of students in reading the Quran: A reflective-critical treatment through action research. International Journal of Instruction, 12, 311-326. https:// doi.org/10.29333/iji.2019.12121a

UNESCO. (2020). Education: From disruption to recovery. https://en.unesco.org/covid19/educationresponse

Wang, C., \& Zhao, H. (2020). The impact of COVID-19 on anxiety in Chinese university students. Frontiers in Psychology, 11(1168). https://doi.org/10.3389/fpsyg.2020.01168

Wiederhold, B. K. (2020). Connecting through technology during the coronavirus disease 2019 pandemic: Avoiding "zoom fatigue". Cyberpsychology, Behavior, and Social Networking, 23(7), 437-438. https://doi.org/10.1089/cyber.2020.29188.bkw

Zarif, M., Mohamad, N., \& Bakar, B. (2014). Assessing Quranic reading proficiency in the j-QAF programme. International Education Studies, 7. https:// doi.org/10.5539/ies.v7n6p1 